\title{
A differential diagnosis for annular lesions: contact dermatitis to transdermal rivastigmine patches
}

\author{
Andre Boo Shern Khoo, Shaheen Haque-Hussain
}

Department of Dermatology, Cambridge University Hospitals NHS Foundation Trust, Cambridge, UK

\section{Correspondence to} Dr Andre Boo Shern Khoo, andre.khoo@cantab.net

Accepted 18 April 2018

\section{DESCRIPTION}

During an appointment for an unrelated condition at a dermatology clinic, a 75 -year-old man was noted to have a number of annular lesions on his trunk. The patient mentioned that he had been prescribed transdermal rivastigmine patches (Alzest $4.6 \mathrm{mg} / 24 \mathrm{~h}$ ) for memory impairment 4 months previously. These were applied and left on for 24 hours before being replaced. He noticed that each patch left a red, pruritic area.

The patient was otherwise well, his only medication being an antihypertensive. He did not have any drug allergies or sensitivity to plasters.

On examination, there were multiple annular lesions scattered over his trunk with a predilection for the flanks (figure 1). These demonstrated an evolution of clinical features; more recent lesions were erythematous, inflamed plaques (figure 1A) which progressed into brown, postinflammatory patches (figure 1B) which gradually faded. All the lesions were well demarcated, circular and approximately $40 \mathrm{~mm}$ in diameter.

Skin reactions to transdermal rivastigmine patches (transdermal therapeutic systems) are relatively common, occurring in $11.4 \%-24.5 \%$ of

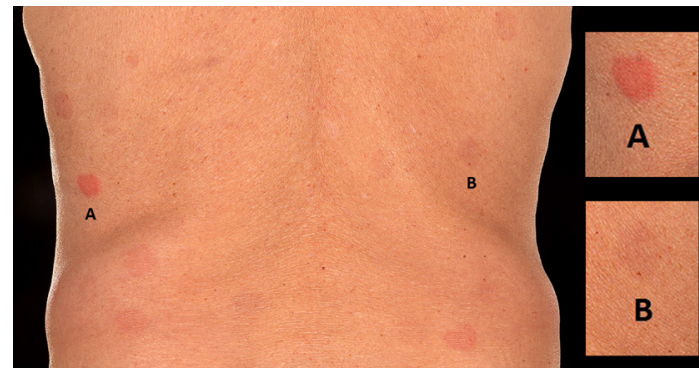

Figure 1 Lower back showing a spectrum of lesion ages. A new inflammatory lesion (A). Older lesion demonstrating fading (B). patients ${ }^{1}$ but the severity of the reaction is usually mild to moderate. ${ }^{12}$ However, unlike a rectangular plaster or dressing, the circular shape of the patch means that the resulting patch of dermatitis can be confused with an endogenous inflammatory rash such as tinea corporis, erythema multiforme or granuloma annulare. The key to the diagnosis usually lies in the history and examination-a spectrum of lesions of varying ages is suggestive, and the use of a patch can be confirmed by the patient or their carers.

\section{Learning points}

Transdermal rivastigmine patches are a cause of contact dermatitis, and the circular shape of the resulting lesion may mimic other inflammatory skin conditions.

- Monomorphic lesions with well-demarcated borders and a spectrum of lesion ages should lead to contact dermatitis as a differential diagnosis.

Contributors ABSK managed the patient and wrote up the case report. $\mathrm{SH}-\mathrm{H}$ is the consultant in charge of the patient and reviewed and approved the case report prior to publication.

Funding The authors have not declared a specific grant for this research from any funding agency in the public, commercial or not-for-profit sectors.

Competing interests None declared.

Patient consent Obtained.

Provenance and peer review Not commissioned; externally peer reviewed.

\section{REFERENCES}

1 Alva G, Cummings JL, Galvin JE, et al. Skin reactions at the application site of rivastigmine patch $(4.6 \mathrm{mg} / 24 \mathrm{~h}, 9.5 \mathrm{mg} / 24 \mathrm{~h}$ or $13.3 \mathrm{mg} / 24 \mathrm{~h}$ ): a qualitative analysis of clinical studies in patients with Alzheimer's disease. Int I Clin Pract 2015:69:518-30.

2 Pregelj P. Safety and tolerability of rivastigmine transdermal patch formulation in newly diagnosed patients with Alzheimer's dementia in naturalistic conditions. Psychogeriatrics 2012;12:165-71.

Copyright 2018 BMJ Publishing Group. All rights reserved. For permission to reuse any of this content visit

http://group.bmj.com/group/rights-licensing/permissions.

BMJ Case Report Fellows may re-use this article for personal use and teaching without any further permission.

Become a Fellow of BMJ Case Reports today and you can:

- Submit as many cases as you like

- Enjoy fast sympathetic peer review and rapid publication of accepted articles

- Access all the published articles

- Re-use any of the published material for personal use and teaching without further permission

For information on Institutional Fellowships contact consortiasales@bmjgroup.com

Visit casereports.bmj.com for more articles like this and to become a Fellow 